\title{
Sitotoksisitas in vitro ekstrak etanolik buah parijoto (Medinilla speciosa, reinw.ex bl.) terhadap sel kanker payudara T47D
}

\author{
Iin Tussanti ${ }^{1}$, Andrew Johan ${ }^{2}$, Kisdjamiatun ${ }^{3}$
}

\begin{abstract}
Background: Several studies focused on phytochemical as agents of cancer prevention and co-chemotherapy. One of Indonesian plant which has edible fruit but it hasn't been completely explored is Medinilla speciosa (Reinw.ex Bl.). Objective : The aim of this study is to examine the cytotoxic activity (IC 50 value) of Medinilla speciosa (Reinw.ex Bl.) fruit ethanolic extract.

Methods : Medinilla speciosa (Reinw.ex Bl.) fruit ethanolic extract was used in this study. The cytotoxic activity was investigated in vitro on human breast cancer T47D cell-line. The cells viability were assessed using MTT colorimetric assay. Breast cancer T47D cell lines was treated with fruit ethanolic extract (10, 25, 50, 100, 250, 500 and $1000 \mu \mathrm{g} / \mathrm{ml})$ for 24 hour of incubation. This study also identified phytochemical compound of the fruit with thin layer chromatography (TLC).

Results: The result showed that ethanolic extract of Medinilla speciosa (Reinw.ex Bl.) has moderate cytotoxicity on breast cancer T47D cell line with IC $C_{50}$ value of $614.50 \mu \mathrm{g} / \mathrm{ml}$ and yield the decrease of cell viability at higher concentration. Medinilla speciosa fruit can not be used as anticancer agent but chemoprevention agent. Phytochemical test showed that the fruit extract contain flavonoid and saponin compound.

Conclusion: Ethanolic extract of Medinilla speciosa fruit exhibited moderate cytotocicity on breast cancer T47D cell lines with $\mathrm{IC}_{50}$ value was $614,50 \mu \mathrm{g} / \mathrm{ml}$ thus it can be used as chemopreventioan agent.
\end{abstract}

Keywords : fruit, Medinilla speciosa (Reinw.ex Bl.), cytotoxixity, MTT assay, breast cancer, T47D cell line

\section{ABSTRAK}

Latar belakang : Beberapa penelitian telah mengkaji komponen fitokimia tumbuhan sebagai agen kemoprevensi atau pendamping kemoterapi kanker. Salah satu jenis tumbuhan Indonesia yang dapat dikonsumsi buahnya dan belum dieksplorasi potensinya terhadap kanker adalah tumbuhan parijoto (Medinilla speciosa). Penelitian ini bertujuan untuk mengetahui sitotoksisitas (nilai IC50) ekstrak etanolik buah parijoto (Medinilla speciosa, Reinw.ex Bl.) secara in vitro.

Metode: Aktifitas sitotoksik ekstrak etanolik buah parijoto (Medinilla speciosa, Reinw.ex Bl.) diuji secara in vitro pada sel kanker payudara T47D dengan metode MTT. Sel kanker payudara T47D diberi perlakuan dengan seri konsentrasi ekstrak 10, 25, 50, 100, 250, 500 dan $1000 \mu \mathrm{g} / \mathrm{ml}$ dan diinkubasikan selama 24 jam. Dalam penelitian ini juga dilakukan uji fitokimia terhadap komponen mayor dalam buah dengan metode kromatografi lapis tipis.

Hasil : Ekstrak etanolik buah Medinilla speciosa menyebabkan sitotoksisitas moderat pada sel kanker T47D dengan nilai IC50 sebesar 614,50 $\mathrm{g} / \mathrm{ml}$. Ini menunjukkan bahwa Medinilla speciosa tidak dapat digunakan sebagai agen antikanker tetapi memiliki potensi sebagai agen kemoprevensi dan menyebabkan berkurangnya viabilitas sel. Uji fitokimia menunjukkan bahwa ekstrak buah Medinilla speciosa positif mengandung flavonoid dan saponin.

Simpulan : Ekstrak etanolik buah Medinilla speciosa menunjukkan sitotoksisitas moderat pada sel kanker T47D dengan nilai IC50 sebesar $614,50 \mu \mathrm{g} / \mathrm{ml}$ dan berpotensi kemoprevensi.

Kata kunci : buah, tumbuhan parijoto (Medinilla speciosa, Reinw.ex Bl.), sitotoksisitas, metode MTT, kanker payudara, sel T47D

\section{PENDAHULUAN}

Kanker payudara merupakan jenis kanker yang paling banyak diderita wanita di seluruh dunia. ${ }^{1}$ Sebagian besar penyakit kanker (lebih dari 95\%) disebabkan karena pengaruh epigenetik dimana gen-gen dipengaruhi oleh berbagai faktor eksternal seperti makanan dan lingkungan. ${ }^{2,3,4}$ Kondisi-kondisi yang

\footnotetext{
${ }^{1}$ SMA Negeri 2, Kabupaten Pati, Indonesia

${ }^{2}$ Bagian Biokimia, Fakultas Kedokteran Universitas Diponegoro, Indonesia

${ }^{3}$ Bagian Parasitologi, Fakultas Kedokteran Universitas Diponegoro, Indonesia
}

dapat menyebabkan perubahan sel normal menjadi sel kanker adalah hyperplasia, dysplasia dan neoplasia. ${ }^{5}$ Pertumbuhan sel yang tidak terkendali disebabkan karena kerusakan DNA sehingga menyebabkan mutasi pada gen vital. $^{6}$ Mencegah proliferasi sel kanker lebih lanjut melalui diet harian dan perubahan gaya hidup perlu dilakukan disamping berbagai upaya kemoterapi karena membunuh satu sel target kanker diantara jutaan sel lain merupakan satu hal yang sangat sulit dilakukan. ${ }^{3}$

Bahan-bahan alami tumbuhan banyak yang telah diekstrak sebagai obat antikanker tetapi khasiatnya dalam hal gizi diperoleh dalam bentuk nutrisi harian. Peran positif buah dan sayur sebagai nutrisi untuk 
kesehatan diindikasikan oleh komponen fitokimia yang terkandung didalamnya. ${ }^{7}$ Salah satu spesies tumbuhan asli Indonesia yang belum dieksplorasi sepenuhnya secara farmakologi adalah tumbuhan parijoto (Medinilla speciosa, Reinw.ex B1.). Parijoto merupakan tumbuhan endemik dari daratan Asia dengan pusat penyebaran di Malaysia, Indonesia dan Pilipina. ${ }^{8,9}$ Di wilayah Jawa Tengah, buah parijoto umumnya dikonsumsi oleh wanita hamil dan digunakan sebagai obat sariawan. Komponen fitokimia yang terkandung dalam buah parijoto adalah flavonoid, saponin dan kardenolin. ${ }^{10}$

Rendahnya risiko kanker kolon, prostat dan payudara pada masyarakat Asia yang mengkonsumsi sayuran atau buah-buahan dibanding negara-negara barat menunjukkan adanya peranan fitokimia tumbuhan sebagai agen antikanker. Sebagian besar fitokimia tumbuhan tergolong sebagai senyawa fenol. ${ }^{11}$ Salah satu jenis fenol yang paling melimpah pada tumbuhan adalah flavonoid. ${ }^{12,13}$ Beberapa studi in vitro menunjukkan beragam efek antikanker dari flavonoid seperti inhibisi pertumbuhan sel dan aktifitas protein-kinase, induksi apoptosis, berkurangnya sekresi matriks metalloproteinase dan menghambat penyebaran tumor. Studi in vivo juga menunjukkan terhambatnya angiogenesis akibat konsumsi flavonoid harian. ${ }^{14,15,16}$

Saponin merupakan komponen fitokimia yang memiliki ciri dapat membentuk busa. Saponin memiliki aktifitas antitumor dengan mekanisme sitotoksik yang berbeda tergantung jenisnya. Saponin dapat mengaktifkan jalur apoptosis secara intrinsik maupun ekstrinsik, menahan siklus sel, memicu autofagi, menghambat angiogenesis, disintegrasi sitoskeleton dan menghambat metastatis. ${ }^{17}$

Pertumbuhan dan viabilitas sel dapat diukur dengan beberapa metode seperti MTT, XTT dan SRB. MTT adalah salah satu metode yang sensitif, kuantitatif dan secara kolorimetri digunakan untuk mengukur viabilitas, proliferasi dan aktivasi sel. Metode ini didasarkan pada kapasitas enzim dehidrogenase mitokondria dalam sel hidup untuk mereduksi garam MTT menjadi formazan berwarna biru atau ungu yang tidak larut air. ${ }^{18}$

Screening awal untuk mengetahui potensi suatu senyawa tumbuhan dilakukan untuk mengetahui adanya efek antimikroba, antioksidan ataupun antikanker. Dalam penelitian ini akan dikaji potensi buah parijoto terhadap kanker melalui uji sitotoksisitasnya secara in vitro terhadap sel kanker payudara T47D dengan menggunakan metode MTT.Selain itudilakukan pula uji fitokimia buah parijoto secara kualitatif dengan metode KLT untuk memastikan adanya kandungan flavonoid dan saponin.

\section{METODE DAN BAHAN}

Bahan utama dalam penelitian ini adalah buah parijoto (Medinilla speciosa, Reinw.ex Bl.) yang diambil dari Kawasan Gunung Muria Kabupaten Kudus Jawa Tengah. Tumbuhan diidentifikasi di Laboratorium Biologi Farmasi Universitas Gadjah Mada, Yogyakarta. Subjek uji yang digunakan adalah sel kanker payudara T47D koleksiCancer Chemoprevention Research Center (CCRC) Fakultas Farmasi UGM.Kultur sel ditumbuhkan dalam media penumbuh DMEM (Dulbecco's Modified Eagle Medium) yang mengandung foetal bovine serum (FBS) $10 \%(\mathrm{v} / \mathrm{v})$ (Gibco), fungizone 0,5 \% (v/v) (Gibco), dan antibiotika penisilin-streptomisin $1 \%$ (v/v) (Gibco). Sel dipanen dari culture dish/flask menggunakan tripsin-EDTA 0,25\% untuk membantu melepaskan sel.

Untuk preparasi ekstrak digunakan etanol $70 \%$ (E.Merck).Uji sitotoksisitas dilakukan dengan metode MTT. Pereaksi kerja dibuat dengan mengencerkan pereaksi stok 10 kali dengan medium DMEM. Pereaksi stopper mengandung natrium dodesil sulfat (SDS, Merck-Schuchardt) $10 \%$ dalam 0,01 N HCl (Merck, Darmstadt, Germany). Uji fitokimia dilakukan menggunakan silika gel 60 F254, fase gerak campuran kloroform:metanol:air (64:50:10),fase gerak campuran etil asetat:asam formiat:asam asetat glassial:air (100:11:11:27), pembanding rutin, pembanding saponin, pereaksi semprot L-B, pereaksi semprotsitroborat. Untuk preparasi larutan uji adalahDMSO (DMSO 99,5\% pro GC, Sigma Aldrich Chemie GmBH, Steinheim, Germany).

Penelitian diawali dengan pembuatan ekstrak etanolik buah parijoto. Larutan uji untuk sitotoksisitas dibuat dengan melarutkan ekstrak etanolik parijoto sebesar $5 \mathrm{mg}$ ke dalam $50 \mathrm{ml}$ DMSO. Larutan stok diencerkan dengan media pertumbuhan DMEM hingga diperoleh seri konsentrasi larutan uji dengan konsentrasi DMSO tidak lebih dari $1 \%$. Konsentrasi larutan uji yang digunakan adalah10, 25, 50, 100, 250, $500,1000 \mu \mathrm{g} / \mathrm{ml}$.Propagasi dan panen sel T47D dilakukan dengan menumbuhkan sel dalam beberapa tissue culture flask atau tissue culture dish dan diinkubasi dalam inkubator $\mathrm{CO}_{2}$ pada suhu $37^{\circ} \mathrm{C}$ dengan aliran $\mathrm{CO}_{2} 5 \%$. Suspensi sel ditambah sejumlah medium sehingga diperoleh konsentrasi sel sebesar $1 \times 10^{4} \mathrm{sel} / \mathrm{ml}$, sel siap untuk penelitian.

Uji sitotoksisitas dilakukan dengan metode MTT dengan menempatkan sel dalam sumuran masingmasing $100 \mu \mathrm{L}$. Tahap selanjutnya adalah pembuatan 
seri konsentrasi. Seri konsentrasi sampel dimasukkan ke dalam sumuran (triplo) dan inkubasikan dalam inkubator $\mathrm{CO}_{2}$. Lama inkubasi tergantung pada efek perlakuan terhadap sel. Jika dalam waktu 24 jam belum terlihat efek sitotoksik, sel diinkubasi kembali selama 24 jam (total 48 jam).

Setelah seri konsentrasi diberi perlakuan dengan reagen MTT $(0,5 \mathrm{mg} / \mathrm{ml})$ selanjutnya diinkubasi selama 2-4 jam di dalam inkubator $\mathrm{CO}_{2}$. Kondisi sel diperiksa dengan mikroskop inverted. Jika formazan telah jelas terbentuk, tambahkan stopper $100 \mu \mathrm{L}$ SDS $10 \%$ dalam $0,1 \mathrm{~N} \mathrm{HCl}$. Bungkus plate dengan kertas atau aluminium foil dan inkubasikan di tempat gelap pada temperatur kamar selama semalam. Absorbansi masing-masing sumuran dibaca dengan ELISA reader dengan $\lambda=550-600 \mathrm{~nm}(595 \mathrm{~nm}$, tekan tombol start). Perhitungan $\mathrm{IC}_{50}$ dilakukan dengan melihat apakah absorbansi yang didapatkan dari ELISA kontrol pelarut lebih rendah dari kontrol sel atau sama dengan kontrol sel.

Analisis data dilakukan dengan MS Excell dengan cara membuat grafik absorbansi vs konsentrasi, kemudian dihitung prosentase sel hidup dan analisis harga $\mathrm{IC}_{50}$ dengan regresi linear. Persamaan regresi linier dicari dari grafik tersebut dengan menampilkan add trendline-regresi linier kemudian lihat parameter $r$ pada persamaan regresi linier. Jika $r$ lebih besar dari $r$ tabel maka persamaan regresi linier memenuhi standar untuk mencari $\mathrm{IC}_{50}$. Masukkan $\mathrm{y}=50 \%$ pada persamaan regresi linier dan cari nilai $x$-nya sehingga diperoleh $\mathrm{IC}_{50}$.

\section{HASIL}

Melalui proses pengeringan dan penyerbukan 1750 gram buah parijoto segar diperoleh serbuk kering sebanyak 179,91 gram. Serbuk kering selanjutnyadimaserasi. Filtrat yang terkumpul selanjutnya dipekatkan dengan rotaryevaporator hingga diperoleh ekstrak kental yang berwarna ungu sebanyak 38,19 gram sehingga rendemen ekstrak yang diperoleh sebesar $21,23 \%$.

Hasil uji sitotoksisitas dengan perlakuan 7 seri konsentrasi ekstrak etanolik buah parijoto terhadap sel T47D menunjukkan adanya penurunan viabilitas sel seiring dengan bertambahnya konsentrasi (Gambar 1).

Pola tersebut menunjukkan adanya penghambatan proliferase sel T47D. Hasil perhitungan $\mathrm{IC}_{50}$ menunjukkan nilai sebesar $614,50 \mu \mathrm{g} / \mathrm{ml}$ sehingga ekstrak etanolik buah parijoto tergolong sitotoksisitas moderat dan berpotensi kemoprevensi. Hal ini menunjukkan bahwa ekstrak buah parijoto tidak dapat digunakan sebagai agen antikanker tetapi dapat digunakan untuk mencegah pertumbuhan sel kanker atau perkembangan sel kanker lebih lanjut.

Hasil uji fitokimia menunjukkan bahwa buah parijoto positif mengandung flavonoid dan saponin (Tabel 1).

Tabel 1. Hasil uji fitokimia ekstrak buah parijoto secara kualitatif dengan metode KLT

\begin{tabular}{clc}
\hline No. & \multicolumn{1}{c}{ Uji Fitokimia } & Hasil \\
\hline 1. & Flavonoid & + \\
\hline 2. & Saponin & + \\
\hline Keterangan $:+=$ positif &
\end{tabular}

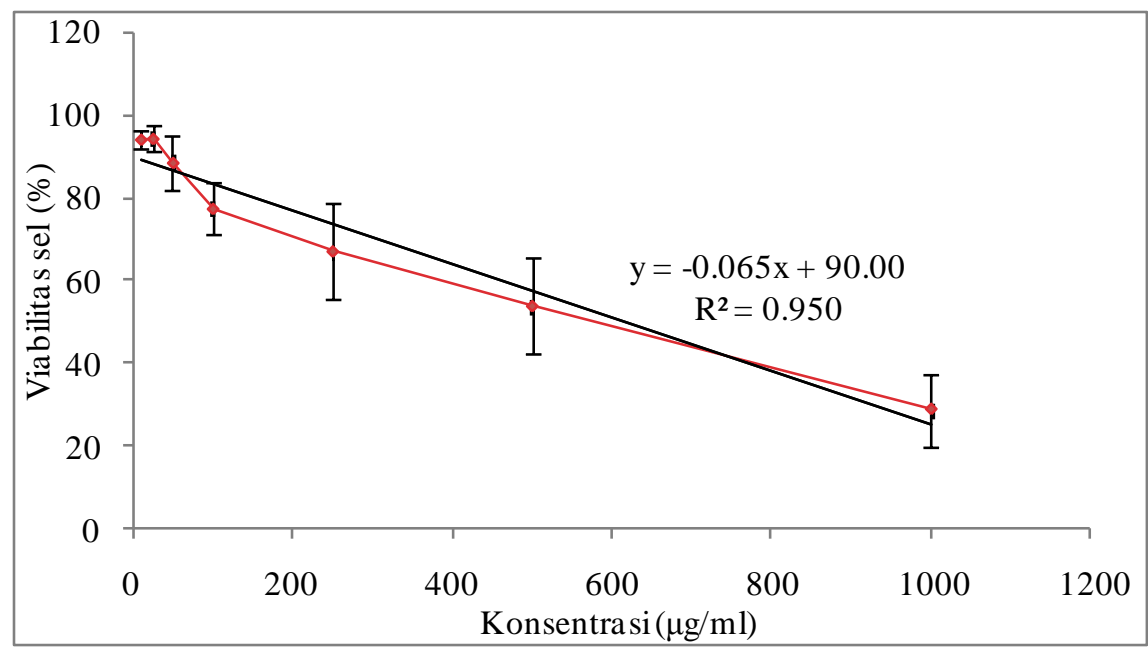

Gambar 1. Kurva viabilitas sel T47D pada berbagai konsentrasi. Uji dilakukan dengan menginkubasi 1 x 104 sel T47D dalam plate 96 well selama 24 jam untuk beradaptasi, kemudian diberi perlakuan sampel konsentrasi 10, 25, 50, 100, 250, 500, $1000 \mu \mathrm{g} / \mathrm{ml}$, kemudian diinkubasi lagi selama $24 \mathrm{jam}$. Setelah 24 jam, sel ditambah reagen MTT, dilanjutkan dengan pembacaan ELISA reader pada $\lambda 595 \mathrm{~nm}$. Profil viabilitas sel disajikan dari rata-rata \pm standard error (SE). 


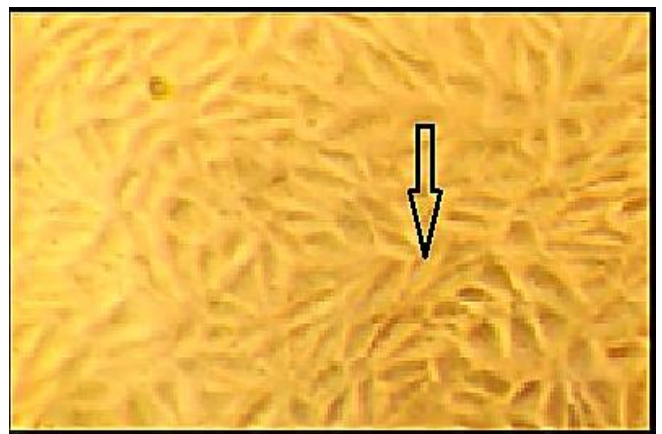

(a)

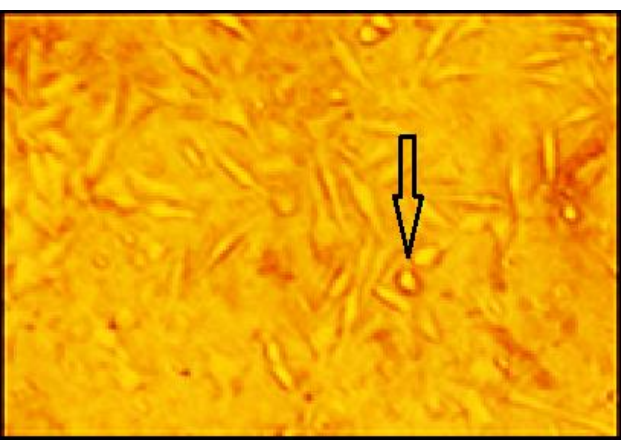

(b)

Gambar 2. Morfologi sel T47D setelah diinkubasi selama 24 jam. Pengamatan morfologi sel pada perlakuan kontrol (a) dan pada konsentrasi $1000 \mu \mathrm{g} / \mathrm{ml}$ (b) dilakukan pada jam ke-24 dengan inverted microscope perbesaran 100x dan difoto menggunakan kamera digital (Canon, Japan).Sel yang hidup bentuknya memanjang pada perlakuan (a),sedangkan sel yang mati berbentuk bulat tampak pada perlakuan (b).

Hasil uji fitokimia menunjukkan bahwa buah parijoto positif mengandung flavonoid dan saponin (Tabel 1).

Tabel 1. Hasil uji fitokimia ekstrak buah parijoto secara kualitatif dengan metode KLT

\begin{tabular}{clc}
\hline No. & \multicolumn{1}{c}{ Uji Fitokimia } & Hasil \\
\hline 1. & Flavonoid & + \\
\hline 2. & Saponin & + \\
\hline Keterangan $:+=$ positif
\end{tabular}

\section{PEMBAHASAN}

Nilai IC $_{50}$ ekstrak etanolik buah parijoto terhadap sel $T 47 D$ sebesar $614,50 \mu \mathrm{g} / \mathrm{ml}$ termasuk dalam kategori sitotoksisitas moderat. Sitotoksisitas dapat dikelompokkan menjadi tiga yaitu: (1) sitotoksik potensial jika $\mathrm{IC}_{50}<100 \mu \mathrm{g} / \mathrm{ml}$, (2) sitotoksik moderat jika $100 \mu \mathrm{g} / \mathrm{ml}<\mathrm{IC}_{50}<1000 \mu \mathrm{g} / \mathrm{ml}$ dan tidak toksik jika $\mathrm{IC}_{50}>1000 \mu \mathrm{g} / \mathrm{ml}$. Kelompok senyawa dengan sitotoksisitas potensial dapat digunakan sebagai agen antikanker sedangkan sitotoksisitas moderat dapat dimanfaatkan untuk kemoprevensi yang dapat mencegah dan menghambat pertumbuhan sel kanker. ${ }^{19}$ National Cancer Institute (NCI) mengelompokkan suatu senyawa tergolong anti kanker jika $\mathrm{IC}_{50}<20 \mu \mathrm{g} / \mathrm{ml}^{20}$

Deteksi terhadap kandungan flavonoid menunjukkan adanya 4 cincin yang mengindikasikan adanya 4 komponen flavonoid. Beberapa jenis komponen fitokimia yang terkandung dalam ekstrak tumbuhan dapat memiliki pengaruh sinergis atau antagonis. Ini berarti bahwa satu komponen dengan komponen lainnya akan berinteraksi sehingga tumbuhan memiliki pengaruh kumulatif yang berbeda dibandingkan masing-masing komponen tunggalnya. Komponen aktif yang diisolasi dari tumbuhan umumnya lebih toksik daripada ekstrak kasarnya yang mengandung campuran beberapa senyawa. ${ }^{21}$ Hal tersebut disebabkan karena komponen-komponen lain memodulasi toksisitas senyawa aktifnya sehingga ekstrak akan bersifat lebih netral secara in vitro maupun in vivo.

Flavonoid bekerja dengan meng-aktivasi protein p53 dan gen-gen targetnya. Pada penelitian ini digunakan sel $T 47 D$ yang merupakan jenis sel kanker yang mengalami mutasi pada gen $p 53$ sehingga tidak mampu melakukan pengendalian siklus sel dan terjadi hambatan dalam apoptosis sel. Sebuah penelitian membuktikan adanya akumulasi protein p53 dan terjadinya apoptosis sel pada sel line non-tumor yang diinkubasi dengan flavonoid. Apoptosis terjadi pada fase $\mathrm{G} 2 / \mathrm{M}$ pada siklus sel. ${ }^{16}$

Selain mengandung fitokimia flavonoid, buah parijoto juga positif mengandung saponin. Saponin mempunyai potensi antikanker. Sitotoksisitas saponin terjadi melalui induksi apoptosis atau non-apoptosis. Beberapa diantaranya adalah kematian sel akibat autofagosit, hambatan siklus sel, menurunnya produksi $N O$ atau disintegrasi sitoskeleton. Jalur apoptosis ekstrinsik dipicu melalui aktifasi reseptor pro-apoptosis khusus di permukaan sel yang distimulasi oleh molekul khusus yaitu ligan proapoptosis (Apo 2L/TRAIL dan CD95L/FasL). Jalur apoptosis intrinsik terjadi dengan cara pelepasan sitokrom-c, depolimerisasi membran mitokondria, downregulasi $\mathrm{Bcl}-2$, stimulasi p53 atau gangguan homeostasis $\mathrm{Ca}^{2+}$. Saponinjuga berperan untuk menghambat angiogenesis. ${ }^{22}$

Pembentukan tumor terdiri dari tiga tahapan yaitu (1) inisiasi, (2) promosi dan (3) progresi. Agen kemoprevensi dibagi menjadi 2 kategori yaitu: (1) blocking agent, yang menghambat zat-zat karsinogen menuju target dan (2) suppresing agent, yang 
menghambat pembentukan malignan dari sel-sel yang ter-inisiasi. ${ }^{14}$ Banyak jenis obat antikanker merupakan senyawa yang diisolasi dari tumbuhan yang umumnya bersifat toksik jika dikonsumsi sebagai bahan pangan. Buah parijoto merupakan buah yang dapat dikonsumsi dan tidak toksik. Efek buah parijoto yang tergolong sitotoksik moderat terhadap pertumbuhan sel kanker dengan indikasi adanya inhibisi pertumbuhan dan peningkatan prosentase kematian sel pada konsentrasi bertingkat menunjukkan adanya pengaruh positif buah parijoto untuk menghambat pertumbuhan sel kanker.

Kemampuan setiap senyawa fitokimia tunggal sebagai agen kemoprevensi untuk menghambat pertumbuhan kanker harus dipahami sebagai hasil dari kombinasi beberapa proses intraseluler, bukan sebagai respon biologis tunggal. ${ }^{7}$ Untuk mengetahui pengaruh setiap komponen aktif buah parijoto maka perlu dilakukan isolasi fitokimia dan diuji sitotoksisitas masing-masing komponennya terhadap sel kanker. Jenis sel kanker yang digunakan dalam uji sitotoksisitas juga berpengaruh terhadap hasil yang diperoleh. Beberapa penelitian membuktikan bahwa setiap jenis sel kanker memiliki respon yang berbedabeda terhadap senyawa tertentu. Efek kemoprevensi dari bahan pangan hanya dapat dicapai pada konsentrasi yang suprafisiologis dan konsentrasi seperti ini mungkin tidak dapat diperoleh melalui diet.

\section{SIMPULAN}

Dari hasil uji sitotoksisitas ekstrak buah parijoto pada sel kanker payudara T47D dengan metode MTT dapat disimpulkan bahwa ekstrak buah parijoto (Medinilla speciosa, Reinw.ex Blume) menunjukkan sitotoksisitas moderat terhadap sel kanker payudara T47D dengan nilai $\mathrm{IC}_{50}$ sebesar $614,50 \mu \mathrm{g} / \mathrm{ml}$ dan tidak berpotensi antikanker tetapi dapat digunakan sebagai agen kemoprevensi. Buah parijoto positif mengandung komponen fitokimia golongan flavonoid dan saponin.

\section{UCAPAN TERIMA KASIH}

Penelitian ini didukung sebagian oleh Biro Perencanaan dan Kerjasama Luar Negeri, Kementrian Pendidikan dan Kebudayaan RI melalui Program Beasiswa Unggulan. Ucapan terima kasih juga disampaikan kepada Cancer Chemoprevention and Research Center (CCRC) Fakultas Farmasi, Universitas Gadjah Mada, Yogyakarta.

\section{DAFTAR PUSTAKA}

1. WHO. Global status report on noncommunicable diseases. Publications of the World Health Organization are available on the WHO web site (www.who.int). 2010.
2. Anand P, Kunnumakara AB, Sundaram C.Cancer is a preventable disease that requires major lifestyle changes. Pharm Res.2008; 25 (9): 2097 116

3. Goel, A. The Role of Phytochemical as AntiInflammatory and Anti-Cancer Agents. Baylor University Medical Center, Dallas, TX.USA. Diunduh dari www.metagenics.com.au

4. Gerhauser C. Cancer cell metabolism, epigenetics and the potential influence of dietary components - A perspective. Biomedical Research .2012; 23.

5. Weinberg RA. The Biology of Cancer. New York: Garland Science. 2007.

6. Ruddon RR. What Makes a Cancer Cell a Cancer Cell? Holland-Frei Cancer medicine - edited by Kufe, DW. RE. Pollock, RR. Weichselbaum, et al (edisi ke-6). Hamilton on BC Decker Inc. 2012.

7. Surh YJ. Cancer Chemoprevention with Dietary Phytochemicals. Nature Reviews/ Cancer. Diakses dari www.nature.com

8. Jorim RY, Korapel S, Legu W et al. An ethno botanical survey of medicinal plants used in the eastern highlands of Papua New Guinea. ResearchJEE. 2012; 8:47. Diunduh dari http://www.ethnobiomed.com/

9. Kimura K, Yumoto T, Kikuzawa K, Kitayama K. Flowering and fruiting seasonality of eight species of Medinilla (Melastomataceae) in a tropical montane forest of Mount Kinabalu, Borneo. TROPICS. 2009; 18. 1-8.

10. Depkes RI. Inventaris Tanaman Obat Indonesia (V). Balitbang Kesehatan. Departemen Kesehatan RI. 2009. p: 123-124

11. Maestri DM, Nepote V, Lamarque AL, Zygadlo JA. Natural products as antioxidants. Phytochemistry: Advances in Research. 2006; 37(2): 661 .

12. Wahle KWJ, Rotondo D, Brown I, Heys SD. Plant Phenolics in the Prevention and Treatment of Cancer, Bio-Farms for Nutraceuticals: Functional Food and Safety Control by Biosensors, edited by Giardi, MT., G. Rea and B. Berra. 2009.

13. Kanadaswami C, Lee LT, Lee PH, Hwang JJ, Ke F, Huang YT, et al. The Antitumor Activities of Flavonoids. Review In Vivo. 2005; 19: 895-910.

14. Nagarani B, Debnath S, Kumar S, Bhattacharjee C, Kumar G. A Review: Herbs Used as Anticancer Agents. International research Journal of Pharmacy. 2009. Available at http://www.irjponline.com

15. Ren W, Qiao Z, Wang H, Zhu L, Zhang L. Flavonoids: Promising Anticancer Agents. Medicinal Research Reviews. 2003; 23 (4): 519534. 
16. Plaumann B, Frirsche M, Rimpler H, Brandner $\mathrm{G}$, et al. Flavonoids Activate Wild-type p53. Oncogene. 1996;13(8):1605-14. Diunduh dari www.ncbi.nlm.nih.gov

17. Man S, Gao W, Zhang F, Liu C. Chemical study and Medical Application of Saponin as Anticancer Agents. 2010. Diunduh dari www.ncbi.nlm.nih.gov

18. Avila EV, Pugsley MK. An Overview of Colorimetric Assay Methods Used to Assess Survival or Proliferation of Mammalian Cells, Review Proc West Pharmacol Soc. 2011; 54: 1014. Diunduh dari http:// www.mwdicine.nevada.edu

19. Prayong $\mathrm{P}$, Barusrux S, Weerapreeyakul N. Cytotoxic activity screening of some indigenous Thai plants. Fitoterapia. 2008; 79(7): 598-601.

20. National Cancer Institute. Understanding Cancer series. Diunduh dari http://www.cancer.gov

21. Celik TA. Potential genotoxic and Cytotoxic Effects of Plant Extracts, diunduh dari http://cdn.intechopen.com/pdfs-wm/26496.pdf

22. Podolak I, Galanty A, Sobolewska D. Saponin as Cytotoxic Agents: A Review. Phytochem. Rev. 2010; 9: 425-474. Diakses dari www.ncbi.nlm.nih.gov 